\title{
Ice core records of levoglucosan and dehydroabietic and vanillic acids from Aurora Peak in Alaska since the 1660s: a proxy signal of biomass-burning activities in the North Pacific Rim
}

\author{
Ambarish Pokhrel ${ }^{1,2,3,4}$, Kimitaka Kawamura ${ }^{1,2}$, Bhagawati Kunwar ${ }^{2}$, Kaori Ono ${ }^{1}$, Akane Tsushima ${ }^{1}$, Osamu Seki ${ }^{1}$, \\ Sumio Matoba ${ }^{1}$, and Takayuki Shiraiwa ${ }^{1}$ \\ ${ }^{1}$ Institute of Low Temperature Science, Hokkaido University, Sapporo, Japan \\ ${ }^{2}$ Chubu Institute for Advanced Studies, Chubu University, Kasugai, Japan \\ ${ }^{3}$ Institute of Science and Technology, Tribhuvan University, Kathmandu, Nepal \\ ${ }^{4}$ Asian Research Center, Kathmandu, Nepal
}

Correspondence: Kimitaka Kawamura (kkawamura@isc.chubu.ac.jp)

Received: 11 February 2019 - Discussion started: 6 March 2019

Revised: 13 September 2019 - Accepted: 16 October 2019 - Published: 17 January 2020

\begin{abstract}
A $180 \mathrm{~m}$ long (343 years) ice core was drilled in the saddle of Aurora Peak in Alaska $\left(63.52^{\circ} \mathrm{N}, 146.54^{\circ} \mathrm{W}\right.$; elevation: $2825 \mathrm{~m}$ ) and studied for biomass-burning tracers. Concentrations of levoglucosan and dehydroabietic and vanillic acids exhibit multidecadal variability, with higher spikes in 1678, 1692, 1695, 1716, 1750, 1764, 1756, 1834, 1898, 1913, 1966 and 2005 CE. Historical trends of these compounds showed enhanced biomass-burning activities in the deciduous broadleaf forests, boreal conifer forests, and/or tundra woodland and mountain ecosystems before the $1830 \mathrm{~s}$ and after the Great Pacific Climate Shift (GPCS). The gradually elevated level of dehydroabietic acid after the GPCS is similar to $p$-hydroxybenzoic acid ( $p$-HBA) from the Svalbard ice core, suggesting common climate variability in the Northern Hemisphere. The periodic cycle of levoglucosan, which seemed to be associated with the Pacific Decadal Oscillation (PDO), may be more involved with the longrange atmospheric transport than other species. These compounds showed significant correlations with global lowertropospheric temperature anomalies (GLTTAs). The relations of the biomass-burning tracers with the PDO and GLTTA in this study suggest that their emission, frequency and deposition are controlled by the climate-driven forces. In addition, historical trends of dehydroabietic and vanillic acids (burning products of resin and lignin, respectively) from our ice core demonstrate the Northern Hemispheric connections to the common source regions as suggested from other ice core
\end{abstract}

studies from Svalbard, Akademii Nauk and Tunu Greenland in the Northern Hemisphere.

\section{Introduction}

Biomass-burning tracers (e.g., levoglucosan and dehydroabietic, vanillic, $p$-hydroxybenzoic and syringic acids) are ubiquitous in the atmosphere and deposited well on ice sheets as snow particles (i.e., precipitation; Pokhrel, 2015; MüllerTautges et al., 2016; Grieman et al., 2018a, b; Shi et al., 2019). Previously, ammonium $\left(\mathrm{NH}_{4}^{+}\right)$, nitrite $\left(\mathrm{NO}_{2}^{-}\right)$, nitrate $\left(\mathrm{NO}_{3}^{-}\right)$and sulfate $\left(\mathrm{SO}_{4}^{2-}\right)$ were used to understand the atmospheric signals of biomass burning and/or the Pioneer Agriculture Revolution (PIA-GREV) in the Northern Hemisphere (Holdsworth et al., 1996; Legrand and Mayewski, 1997; Legrand et al., 2016). For instance, a signal of biomass burning is ammonium (e.g., $\left[\mathrm{NH}_{4}\right]_{2} \mathrm{SO}_{4}$ ) in snow particles, which is a constituent of forest fire smoke (Holdsworth et al., 1996; Tsai et al., 2013). Biomass-burning activities such as forest fires and residential heating may affect climate change (Legrand and De Angelis, 1996; Savarino and Legrand, 1998; Gambaro et al., 2008; Keywood et al., 2011).

Ice core records archive the long-term changes in deposition and concentration of organic (e.g., biomass-burning tracers, ethane, formate, acetate, dicarboxylic acids, pyruvic acid and $\alpha$-dicarbonyls) and inorganic species (e.g., $\mathrm{NH}_{4}^{+}$, 
$\mathrm{SO}_{4}^{2-}, \mathrm{NO}_{3}^{-}, \mathrm{K}^{+}$and $\mathrm{NO}_{2}^{-}$; Yang et al., 1995; Legrand and Mayewski, 1997; Andreae and Merlet, 2001; Kaufmann et al., 2010; Lamarque et al., 2010; Wolff et al., 2012; Kawamura et al., 2001, 2012; Kehrwald et al., 2012; Legrand et al., 2016; Shi et al., 2019). Many studies have shown that there are some discrepancies of temporal and spatial biomassburning activities in ice core proximity records (Legrand et al., 1992, 1996, 2016; Kaplan et al., 2006; Kawamura et al., 2012; Grieman et al., 2015, 2017, 2018a, b; Rubino et al., 2016; Zennaro et al., 2014; You and $\mathrm{Xu}, 2018$ ) in both the Northern Hemisphere (NH) and Southern Hemisphere (SH).

For example, proxy records of biomass-burning activities from Lomonosovfonna, Svalbard (Grieman et al., 2018a), showed different trend between vanillic acid and $p$ hydroxybenzoic acid ( $p$-HBA) within the same ice core sample. Interestingly, ice core records of the North Greenland Eemian (NEEM; Zennaro et al., 2014, 2018) have demonstrated a human impact on the climate system for 4000 years. A different circumpolar region in the $\mathrm{NH}$ has a different atmospheric air mass circulation with different results of biomass-burning tracers such as levoglucosan; vanillic, dehydroabietic and syringic acids; and ethane, ammonium and other carboxylic acids, suggesting potential discrepancies in the origin, transport and deposition of these compounds on the ice crystals.

These discrepancies of biomass-burning tracers in different ice core records may suggest the different glaciochemical cycles in the NH and SH throughout decadal to centennial and even millennial periods. For example, centennial and/or shorter timescales of trends exhibited different elevated or suppressed concentration trends of $p$-HBA or vanillic acid during $1600 \mathrm{CE}$ and vanillic or $p$-HBA during 20002008 CE (Grieman et al., 2018a). Similarly, the Svalbard ice core record (Grieman et al., 2018a) showed different elevated or suppressed historical trends or peaks from the NEEM ice core of Greenland (Zennaro et al., 2018). These results most likely suggest the occurrence of changing or shifting contributions of source regions with the different ecosystems of trees, shrubs and grasses to the sampling sites.

There are a few ice core studies of biomass-burningderived specific organic tracers, including levoglucosan, which is a pyrolysis product of cellulose and hemicellulose, and other sugar compounds such as mannosan and galactosan as well as dehydroabietic and vanillic acids, which are biomass-burning products of resin and lignin, respectively (Kawamura et al., 2012; Legrand et al., 2016; Grieman et al., 2017, 2018a, b; Zennaro et al., 2018; Li et al., 2018; You et al., 2019). Kawamura et al. (2012) reported specific biomass-burning tracers (levoglucosan, dehydroabietic and vanillic acid) for an ice core (1693-1997 CE), collected from the Kamchatka Peninsula $\left(56^{\circ} 04^{\prime} \mathrm{N}, 160^{\circ} 28^{\prime} \mathrm{E}\right.$; elevation: 3903 m) in the western North Pacific Rim.

In this paper, we report levoglucosan, dehydroabietic acid and vanillic acid in an ice core collected from Aurora Peak in southern Alaska, an inland site facing the northeastern Pacific
Ocean (Fig. 1). This study covers 1665-2008 CE, which can help with better understanding the historical variability in the atmospheric transport of biomass-burning tracers between the western North Pacific (Kawamura et al., 2012) and eastern North Pacific (this study). We also compare the present results with other ice core studies from Greenland, Svalbard and Akademii Nauk in the NH. The results of this study can further disclose the database of levoglucosan, dehydroabietic and vanillic acids from the alpine glaciers in the North Pacific Rim to explore their possible sources, origin, long- and short-range atmospheric transport, ecological changes, and climate variability in the $\mathrm{NH}$.

\section{Materials and methods}

An ice core ( $180.17 \mathrm{~m}$ deep and 343 years old) was drilled in the saddle of the Aurora Peak in southern Alaska (location: $63.52^{\circ} \mathrm{N}, 146.54^{\circ} \mathrm{W}$; elevation: $2825 \mathrm{~m}$; see Fig. 1 for sampling site). The annual mean temperature at the site was $-2.2^{\circ} \mathrm{C}$, which matched with the temperature at the $10 \mathrm{~m}$ depth in the borehole ice. The annual accumulation rate of snow has been $8 \mathrm{~mm} \mathrm{yr}^{-1}$ since 19 century and $23 \mathrm{~mm} \mathrm{yr}^{-1}$ after the Great Pacific Climate Shift (GPCS; cold water masses have been replaced by warm water since 1977, e.g., Meehl et al., 2013). This $180 \mathrm{~m}$ long core was divided into $\sim 50 \mathrm{~cm}$ pieces and directly transported to the laboratory of the Institute of Low Temperature Science (ILTS), Hokkaido University, Japan, and stored in a dark, cold room at $-20^{\circ} \mathrm{C}$ until analysis.

The ice core ages were determined by using annual counting of hydrogen isotopes $(\delta \mathrm{D})$ and $\mathrm{Na}^{+}$seasonal cycles (Tshushima, 2015; Tsushima et al., 2015), with tritium-peak reference ranges between 1963 and 1964 and volcanic eruptions of Mt. Spurr and Mt. Katmai in 1992 and 1912, where the dating error was \pm 3 years at the $0.02 \mathrm{~m}$ resolution. These ice core samples $(50 \mathrm{~cm}$ long, one-fourth cut by circumference) were mechanically shaved off $(\sim 5-10 \mathrm{~mm}$ thickness of the outer-core surface) on a clean bench at $-15^{\circ} \mathrm{C}$ in a cold room. A ceramic knife was used to avoid a possible contamination during sample collection. We cleaned the ceramic knife (total of 12 times) three times by using organic free pure water (Milli-Q water), methanol $(\mathrm{MeOH})$, dichloromethane (DCM), and a 2:1 mixture of DCM and $\mathrm{MeOH}$. These scraped ice samples were placed in a clean glass jar (Iwaki Glass, $1000 \mathrm{~mL}$ ) for $24 \mathrm{~h}$ with aluminum foil as a cap cover in a level-2 clean room. After $24 \mathrm{~h}$, these shaving ice core samples were kept at room temperature (ca. $25^{\circ} \mathrm{C}$ ) after a small amount (ca. $10 \mathrm{mg}$ ) of $\mathrm{HgCl}_{2}$ was added (Pokhrel, 2015). Finally, the thawed sample was transferred into a $800 \mathrm{~mL}$ pre-cleaned brown glass bottle and stored at $4{ }^{\circ} \mathrm{C}$. The clean glass jars and bottles were preheated at $450^{\circ} \mathrm{C}$ for $12 \mathrm{~h}$. The total number of ice core sections was 147 , with a sampling frequency of $\sim 40 \%$ of the ice core. 


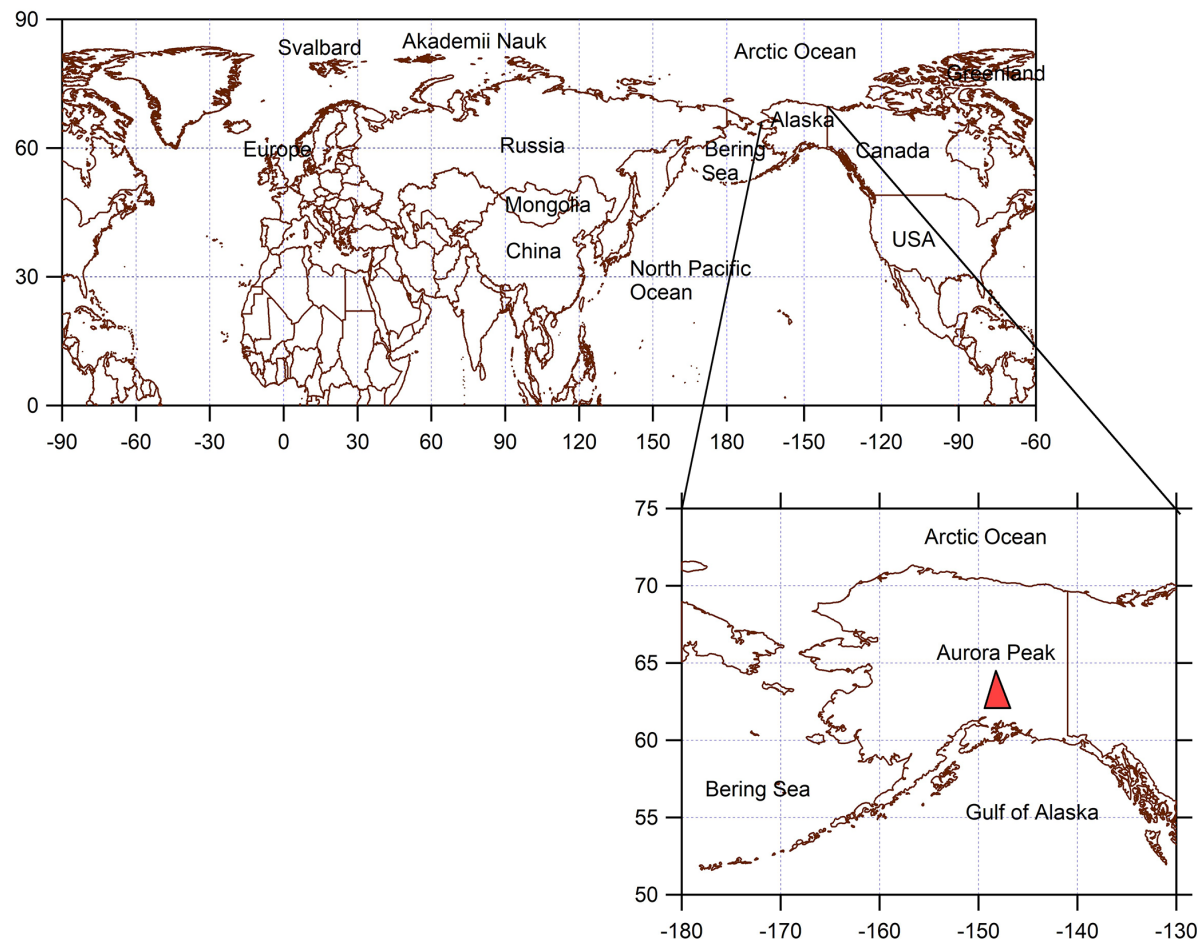

Figure 1. Geographical location of Aurora Peak in Alaska, where a $180 \mathrm{~m}$ long ice core was drilled into the saddle of this peak in 2008.

These melted ice core samples $(150 \mathrm{~mL})$ were concentrated to near-dryness using a rotary evaporator under a vacuum in a pear-shaped flask $(300 \mathrm{~mL})$ and extracted by a mixture of $\mathrm{DCM} / \mathrm{MeOH}(2: 1)$ using an ultrasonic bath. The extracts were transferred to $1.5 \mathrm{~mL}$ glass vial and dried under a nitrogen stream. Extracts were derivatized with $99 \% \mathrm{~N}$, O-bis-(trimethylsilyl)trifluoroacetamide (BSTFA) $+1 \%$ trimethylchlorosilane (TMCS) and $10 \mu \mathrm{L}$ of pyridine at $70^{\circ} \mathrm{C}$ for $3 \mathrm{~h}$ (Fu et al., 2011; Kawamura et al., 2012). Before injection to gas chromatography-mass spectrometry (GC-MS), the known volume of internal standards ( $\mathrm{n}-\mathrm{C}_{13}$ alkane) was added. GC peaks were analyzed by GC-MS: a Hewlett Packard Model 5973 MSD coupled to a HP 6890 GC using a capillary column (HP$5 \mathrm{MS}, 30 \mathrm{~m} \times 0.32 \mathrm{~mm}$ inner diameter, $0.25 \mu \mathrm{m}$ film thickness) installed with a splitless injector. The GC oven temperature was programmed from $50^{\circ} \mathrm{C}(2 \mathrm{~min})$ to $120^{\circ} \mathrm{C}$ at $30^{\circ} \mathrm{C} \mathrm{min}^{-1}$ and then to $300^{\circ} \mathrm{C}$ at $6^{\circ} \mathrm{C} \mathrm{min}^{-1}$ and maintained at $300^{\circ} \mathrm{C}$ for $20 \mathrm{~min}$. Helium was used as a carrier gas. The GC-MS was operated in scan mode $(\mathrm{m} / z=50$ 650 ) and with an electron impact mode at $70 \mathrm{eV}$ (Pokhrel et al., 2016).

Fragment ions at $m / z=217,204$ and 333 for levoglucosan; $m / z=239$ for dehydroabietic acid; and $m / z=297$, 312 and 267 for vanillic acid were processed on the ChemStation software and used for quantification. Peaks were further confirmed by comparing the mass spectra with those of authentic standards and the mass spectral data in the
NIST Wiley library. An aliquot of authentic standard solution $(10 \mu \mathrm{L})$ containing levoglucosan, dehydroabietic acid, vanillic acid and syringic acid (5.5, 4.7 and $4.2 \mathrm{ng}_{\mu} \mathrm{L}^{-1}$, respectively) was spiked to organic free Milli-Q water $(200 \mathrm{~mL})$ placed in the pear-shaped flask. The water sample was concentrated and dried by the procedure described above. The concentrations were derivatized with BSTFA, and peaks were analyzed by GC-MS. The recoveries of the spiked samples of levoglucosan, dehydroabietic acid and vanillic acid were more than $83 \%$. Duplicate analyses were conducted to check for the analytical error of target compounds, which was less than $9 \%$. Laboratory blanks was measured using Milli-Q water $(200 \mathrm{~mL})$. The procedural blanks showed no detectable peaks of these compounds. Detection limits of these species were $0.002-0.005 \mathrm{ng}$ per $\mathrm{kg}$ ice.

We performed cluster analysis for $10 \mathrm{~d}$ back trajectories at $500 \mathrm{hPa}$ from 2002 to 2007 (Fig. 2a-f), computed for every $6 \mathrm{~h}$, which reveal that long-range atmospheric circulation was significant in the study site of Aurora Peak. To identify the possible source regions of biomass-burning events, we prepared annual composite maps (2002 to $2008 \mathrm{CE}$ ) of the Moderate Resolution Imaging Spectroradiometer (MODIS) effective hotspot (Fig. 2a-f) from the Earth Observing System Data and Information System (EOSDIS) using the Terra and Aqua satellites of NASA (https://earthdata.nasa.gov/data/ near-real-time-data/firms/active-fire-data, last access: $7 \mathrm{Au}-$ gust 2019). The $10 \mathrm{~d}$ back-trajectory analysis from 2002 to 2007 showed that Aurora Peak received air masses from the 
North Pacific Ocean, eastern Asia, Siberia, Europe, Canada and higher latitudes of Alaska (Fig. 2a-f). Similar sources were reported using a $10 \mathrm{~d}$ back trajectory from 1992-2002 (>300 hPa; Yasunari and Yamazaki, 2009). The Kamchatka Peninsula also receives air masses from China, Mongolia, Siberia, eastern Russia and Europe (Kawamura et al., 2012).

\section{Results and discussion}

Anhydrosugars such as levoglucosan are ubiquitous in the atmosphere; these are emitted significantly from biomassburning activities and deposited on the ice crystals and contribute to water-soluble organic carbon (WSOC; Zennaro et al., 2014; Verma et al., 2015; Gao et al., 2015; Legrand et al., 2016; Grieman et al., 2017, 2018a, b; Li et al., 2018; You et al., 2019). They are produced from the pyrolysis and combustion of cellulose and/or hemicellulose from wildfires and domestic wood fires at temperatures above $300^{\circ} \mathrm{C}$ (Shafizadeh, 1984; Fraser and Lakshmanan, 2000; Simoneit, 2004) during the smoldering stage of a fire. Recently, Kuo et al. (2011) reported that levoglucosan and its isomers are produced at temperatures up to $350^{\circ} \mathrm{C}$. Many studies have shown that levoglucosan is the most abundant anhydrous monosaccharide (Engling et al., 2006; Hoffmann et al., 2010; Kuo et al., 2011), which is tracked by other species of anhydro-monosaccharides, e.g., mannosan, galactosan and/or dehydroabietic acid. Such specific characters and the sources can make levoglucosan a unique tracer ( $\mathrm{Si}$ moneit et al., 1999; Jordan et al., 2006) in southern Alaska, as shown in Fig. 1.

In addition, historical trends of biomass-burning tracers may represent the bulk effects of emissions, transport, transformations, and the depositional and post-depositional process on the ice crystals (Grieman et al., 2017). A comparison of this study (e.g., concentration trends) with other ice core studies suggested that these compounds are well captured in the atmosphere and deposited to the ice sheets. Back trajectories of this study and other ice core studies suggested common source regions (e.g., Russia, Siberia and eastern Asia); it takes several days for the compounds to reach the sampling sites (e.g., Tunu, Greenland; Svalbard; Akademii Nauk; and Aurora Peak in Alaska).

\subsection{Levoglucosan}

This study showed that average concentration of levoglucosan (BDL - below detection limit - range: BDL-20800; average: $543 \pm 2340 \mathrm{ng}$ per $\mathrm{kg}$ ice) is 8.6 times higher than that of dehydroabietic acid (range: BDL-556; average: $62 \pm$ $97 \mathrm{ng}$ per $\mathrm{kg}$ ice) and 400 times higher than that of vanillic acid (range: BDL-18.6; average: $1.5 \pm 2.9 \mathrm{ng}$ per kg ice) for 1665-2008 CE. It should be noted that combustion of lignite (lignite includes fossilized cellulose) or hemicellulose emits levoglucosan and its isomers, e.g., mannosan and galactosan (Hoffmann et al., 2010; Kuo et al., 2011). However, we did not detect these isomer compounds (BDL). In contrast, higher concentrations of these isomers and levoglucosan were reported in aerosol samples collected from the oceans via an "around-the-world cruise" (Fu et al., 2011), Mt. Tai in the North China Plain (Fu et al., 2008) and urban tropical India (Fu et al., 2010) using the same method.

Levoglucosan may not be as stable as previously thought in the atmosphere (Fraser and Lakshmanan, 2000; Hoffmann et al., 2010); however, its concentrations are not seriously influenced during transport for several days (Fraser and Lakshmanan, 2000; Lai et al., 2014). Hence, we may speculate that levoglucosan could be stable enough in the ice core studies. However, degradation of levoglucosan depends upon the $\mathrm{OH}$ radical (Hennigan et al., 2010), which is automatically affected by relative humidity of the atmosphere and air mass aging during long-range atmospheric transport from Japan, China, Mongolia, Siberia and Russia to Aurora Peak.

Levoglucosan showed higher concentrations in the 1660s to the 1830s (Fig. 3a), with sporadic peaks in 1678 (ice core depth: $174.6 \mathrm{~m}$; concentration: $593 \mathrm{ng}$ per kg ice), 1692 (172.2 m; $704 \mathrm{ng}$ per $\mathrm{kg}$ ice), 1695 (170.3 m; $1250 \mathrm{ng}$ per $\mathrm{kg}$ ice), 1716 (165.6 m; 990 ng per kg ice), 1750 (156.7 m; $913 \mathrm{ng}$ per kg ice), 1764 ( $151.5 \mathrm{~m}$; $1433 \mathrm{ng}$ per kg ice), 1786 (147.3 m; $7057 \mathrm{ng}$ per kg ice), 1794 (146.1 m; 3302 ng per kg ice) and 1834 (138.4 m; $944 \mathrm{ng}$ per kg ice) above its average concentration (542 ng per $\mathrm{kg}$ ice). Source regions of these higher spikes could be eastern Asia, eastern Russia, Siberia, and the higher latitudes of Alaska and Canada. For instance, Ivanova et al. (2010) reported the frequently occurring heavy forest fires (e.g., boreal forest) in spring, summer and autumn in eastern Siberia in the past, which is a potential source region to Alaska. This study showed higher concentrations of levoglucosan before the 1840s (Fig. 3a). Marlon et al. (2008) further confirmed that there was intensive biomass burning between the 1750 s and 1840 s on a global scale, which is linked to increasing anthropogenic activities (e.g., population growth and land-use change).

Similarly, we detected higher spikes of levoglucosan in 1898 (120.7 m; $577 \mathrm{ng}$ per kg ice), 1913 (114.8 m; $20800 \mathrm{ng}$ per $\mathrm{kg}$ ice), 1966 (77.7 m; $692 \mathrm{ng}$ per $\mathrm{kg}$ ice) and 2005 ( $13.7 \mathrm{~m}$; $598 \mathrm{ng}$ per $\mathrm{kg}$ ice) above the average concentration (542 ng per kg ice). Figure 3a clearly shows lower levels than the average after the 1830s (except for 1898, 1913, 1966 and $2005 \mathrm{CE}$ ). This decline could be attributed to less forest fire activity due to intensive grazing, agriculture and forest fire management systems (Marlon et al., 2008; Eichler et al., 2011). It should be noted that charcoal signals are scarce for Siberian regions compared to North American and European ice core records (Eichler et al., 2011). Moreover, two-thirds of Earth's boreal forest $\left(17 \times 10^{9}\right.$ ha) lies in Russia, which is a potential source of forest fires with a significant effect on a global air quality (Isaev et al., 2002; Eichler et al., 2011).

Mt. Logan in Canada, the Greenland Ice Sheet Project 2 (GISP2) and 20D (older than the 1850s) ice core records of 

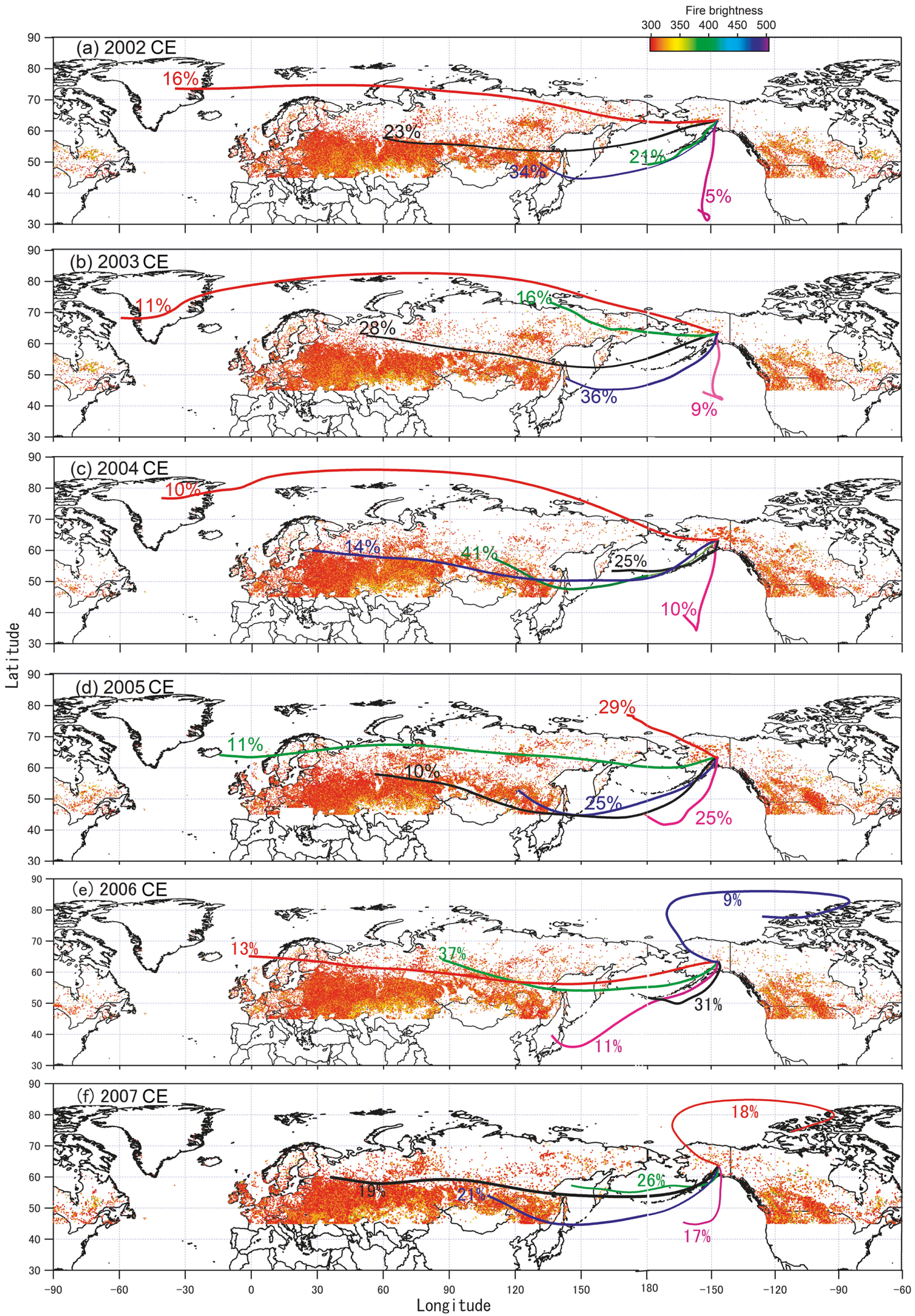

Figure 2. The MODIS fire spots together with $10 \mathrm{~d}$ back-trajectory analysis (a-f) of Alaska from 2002 to 2007. 

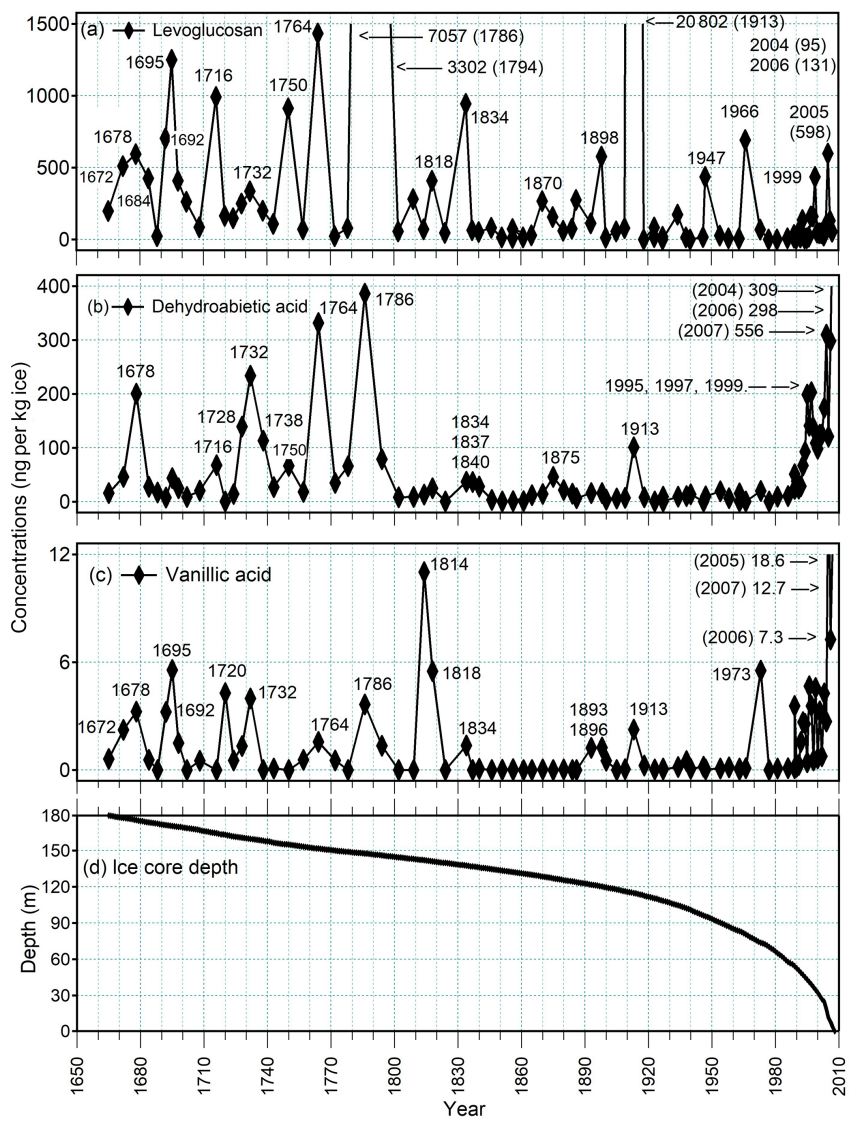

Figure 3. Concentration changes of (a) levoglucosan and (b) dehydroabietic and (c) vanillic acids in the ice core, and (d) depth of the ice core collected from Aurora Peak in Alaska for 1665-2008 CE.

Greenland are characterized by higher spikes of $\mathrm{NH}_{4}^{+}$coupled with a relatively uniform summertime and wintertime minimum (Whitlow et al., 1994). We obtained higher spikes of levoglucosan before the 1840s (Fig. 3a), which is consistent with higher spikes of $\mathrm{NH}_{4}^{+}$in $1770-1790$ and 1810-1830 in the Mt. Logan data (e.g., Whitlow et al., 1994). This comparison suggests similar source regions of $\mathrm{NH}_{4}^{+}$for different sampling sites before the 1830s. In contrast, Mt. Logan data showed higher spikes of $\mathrm{NH}_{4}^{+}$in the intervals of 1850-1870 and 1930-1980, which is dissimilar (except for two points) to our results from Aurora Peak (Fig. 3a). It should be noted that Greenland ice core records (GISP2 and 20D) showed lower spikes of $\mathrm{NH}_{4}^{+}$compared to Mt. Logan (Whitlow et al., 1994) during these intervals (1850-1870 and 1930-1980). This is consistent with the results of Aurora Peak (except for 1966), again suggesting similar source regions (Holdsworth et al., 1992; Davidson et al., 1993; Whitlow et al., 1994). The potential source regions for Greenland ice cores include northern North America, Europe and Siberia, which are also likely source regions for Mt. Logan (Holdsworth et al., 1992; Davidson et al., 1993; Whitlow et al., 1994; Legrand et al., 2016). These regions may be associated with higher spikes in ice cores from Mt. Logan, Greenland and Aurora Peak in Alaska.

Except for a few points, e.g., 1999 (436 ng per kg ice) and 2005 (598 ng per kg ice), concentrations of levoglucosan drastically decreased in 1980-2008. This decrease implies that forest fire activities could be depressed by many factors. For instance, central and eastern Siberian forest fire activities were controlled by strong climate periodicity, e.g., during the Arctic Oscillation (AO), El Niño-Southern Oscillation (ENSO), intensification of the hydrological cycle in central Asia, and other human activities in the NH (Robock, 1991; Wallenius et al., 2005; Balzter et al., 2007; Achard et al., 2008; Eichler et al., 2011). Eichler et al. (2009) further confirmed that from 1816 to 2001, higher amounts of $\mathrm{NH}_{4}^{+}$ and formate $\left(\mathrm{HCOO}^{-}\right)$were directly emitted from biogenic sources rather than biomass burning (Olivier et al., 2006) in the Belukha glacier in the Siberian Altai Mountains. Moreover, lower concentrations of charcoal between 1700 and 2000 in the Altai Mountains further suggest that forest fire activities were weaker than anthropogenic activities in the source regions (Eichler et al., 2011).

Similarly, the sparsity of levoglucosan after the 1840 s compared to 1660 s to 1840 s means low intensity of biomass burning and/or significant deposition before reaching to the saddle of Aurora Peak, except for 1898, 1913, 1947 and $1966 \mathrm{CE}$, which could be due to a point source around Alaska for levoglucosan rather than long-range atmospheric transport. For example, higher spikes of $\mathrm{NH}_{4}^{+}$at Mt. Logan during 1900-1990 CE likely originated from central and eastern Siberia (Robock, 1991), which is dissimilar to the source regions in this study. The only exception is in 1966 (2000 ng per kg ice), suggesting that local biomass burning and/or different source regions could be activated for levoglucosan, which is important in southern Alaska during this period. Moreover, vanillic acid (VA) and $p$-hydroxybenzoic acid ( $p$ HBA) of Svalbard and Akademii Nauk (Eurasian Arctic) did not show similar trends (Grieman et al., 2017, 2018a). This further suggests that central and eastern Siberia did not contribute this compound significantly during this period (19001990 CE) compared to other ice core studies (e.g., Fig. 4a-e) and/or that atmospheric circulations could be shifted.

The above results suggest the following: (a) heavy biomass burning could be activated in the source regions; (b) shortrange air mass circulation could quickly reach southern Alaska, causing higher levels of levoglucosan; (c) dilution and/or scavenging of a biomass plume en route could be maximized after 1830s, whose mechanisms could be associated with dry and wet deposition, diffusion, and degradation by hydroxyl radicals in the atmosphere during longrange atmospheric transport, and (d) a common NH summertime biomass-burning plume could be significantly deposited during short-range atmospheric circulation on the exposed surface area of the glaciers. Particularly, Mt. Logan, Svalbard, Tunu in Greenland and Aurora have common source regions, e.g., Russia and/or Siberian forest as well 

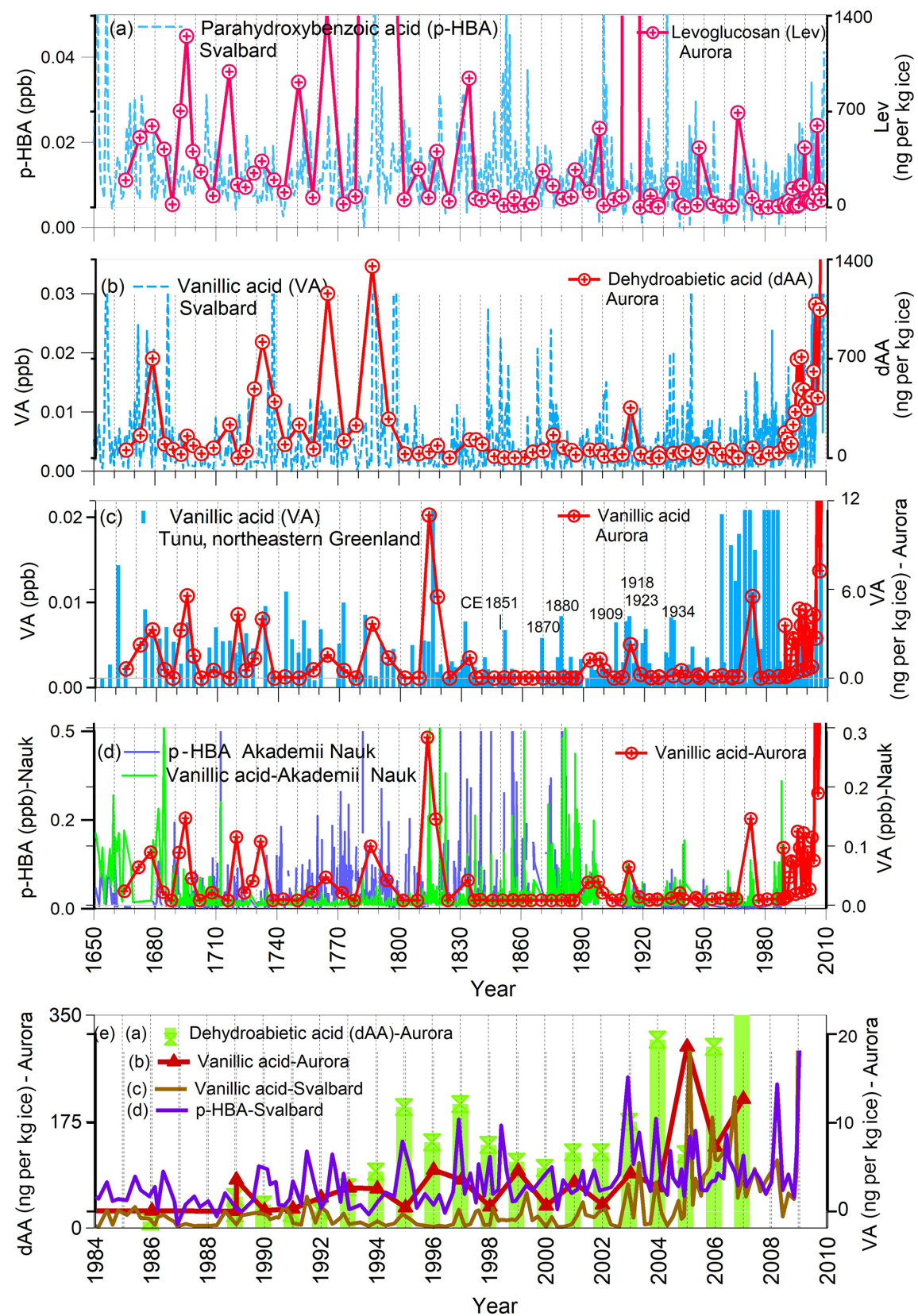

Figure 4. Historical trends of (a) $p$-hydrobenzoic acid ( $p$-HBA) of Svalbard; (b) vanillic acid (VA) of Svalbard; (c) VA of Tunu, Greenland; (d) $p$-HBA and VA of Akademii Nauk, with levoglucosan (Lev), dehydroabietic acid (dAA) and VA of Aurora Peak; and (e) historical trends of dAA and VA of Aurora and VA and $p$-HBA of Svalbard after the Great Pacific Climate Shift (1977-2007 CE). p-HBA and VA of Svalbard are adopted from Grieman et al. (2018a), VA of Tunu, northeastern Greenland, is adopted from Grieman et al. (2018b), and $p$-HBA and VA of Akademii Nauk are adopted from Grieman et al. (2017).

North American and Canadian forest (Fig. 4a-e). These considerations support the fact that Alaskan glaciers can preserve most biomass-burning events in the circumpolar regions, which occurred in the source regions of Siberia, eastern Asia, Canada and Alaska.

Hence, these historical records of levoglucosan before the 1830s suggest that long-range atmospheric transport was sig- nificant rather than short-range transport from intense and widespread forest fires. For instance, forest fire intensity in around 1660-1830 CE could be induced by lightning during drought seasons in the Siberian regions as well as extensive burning to clear land for agriculture purposes in the NH (Whitlow et al., 1994; Legrand et al., 2016; Grieman et al., 2017, 2018a, b). 
A declining trend in the concentrations of levoglucosan after the 1830s (except for few points) showed that sources could be changed significantly and/or forest fire activities could be suppressed and/or controlled in 1830-1980 (Whitlow et al., 1994). It should be noted that $1400 \mathrm{CE}$ to the end of the $1700 \mathrm{CE}$ is the Little Ice Age (LIA), and the period after the LIA until the late 1800 s is considered to be the extended Little Ice Age (ELIA; Mann et al., 2009; Divine et al., 2011). This study shows that intense biomass-burning activities (higher spikes) before the 1830s are somewhat similar to historical records of $p$-HBA and vanillic acid of Lomonosovfonna (Svalbard) and the Akademii Nauk ice core in the $\mathrm{NH}$ (Grieman et al., 2017, 2018a) except for some points (Fig. 4a, b, d). Hence, recent changes in the concentration trends in the Alaskan ice core are thought to be driven by climate. These climate-driven effects are further discussed in later Sect. 3.4.

\subsection{Dehydroabietic acid}

Dehydroabietic acid is produced by pyrolytic dehydration of abietic acid from conifer resin. In other words, dehydroabietic acid is produced during the burning process of conifer resin (Simoneit et al., 1993; Kawamura et al., 2012). It can be used as a specific biomass-burning tracer for conifer trees and other resin-containing softwoods in an ice core study. Dehydroabietic acid was detected as the second most abundant species (range: BDL-556; average: 62.4 $\pm 97.2 \mathrm{ng}$ per $\mathrm{kg}$ ice); its concentrations are 9 times lower than levoglucosan but more than 46 times higher than vanillic acid (range: BDL-18.6; average: $1.62 \pm 2.96 \mathrm{ng}$ per kg ice). Dehydroabietic acid showed higher spikes than its average concentration (62.4 ng per kg ice) in 1678 (ice core depth in meters - $173.9 \mathrm{~m} ; 200 \mathrm{ng}$ per $\mathrm{kg}$ ice), 1716 (165.3 m; 67.5 ng per $\mathrm{kg}$ ice), 1728 (161.5 m; $139 \mathrm{ng}$ per kg ice), 1732 (159.6 m; $233 \mathrm{ng}$ per $\mathrm{kg}$ ice), 1738 (158.3 m; $113 \mathrm{ng}$ per kg ice), 1750 $(156.7 \mathrm{~m} ; 66.9 \mathrm{ng}$ per $\mathrm{kg}$ ice), 1764 (151.5 m; $331 \mathrm{ng}$ per $\mathrm{kg}$ ice), 1786 (147.3 m; $386 \mathrm{ng}$ per kg ice), 1794 (146.1 m; $78.6 \mathrm{ng}$ per $\mathrm{kg}$ ice), 1913 (114.8 m; $101 \mathrm{ng}$ per kg ice) and each consecutive year from 1994 to $2007 \mathrm{CE}$ (depth range is 44.8-0.88 m; with 92.8, 199, 141, 203, 136, 109, 98.5, 124, $124,174,309,131,298$ and $555 \mathrm{ng}$ per kg ice, respectively). Vanillic acid from Svalbard (Grieman et al., 2018a) showed similar spikes with dehydroabietic acid in this study from the 1660 s to the 1790s. In addition, the Svalbard ice core showed relatively lower spikes from the 1800 s to the 1980 s as compared to those from the 1660s to the 1790s. In contrast, $p$ HBA in this study did not show a similar trend to Svalbard (Fig. 4a, b).

These periods are consistent with the higher spikes of levoglucosan, except for a few points (e.g., 1734-1738 CE) before 1990 CE (Fig. 3a, b). The historical trend of dehydroabietic acid is also similar to that of levoglucosan before 1980, which is consistent with Kamchatka ice core records (Kawamura et al., 2012). In contrast, the Kamchatka ice core showed a gradual increase in dehydroabietic acid af- ter the 1950s. However, we found an abrupt increase for dehydroabietic and vanillic acids in the Alaskan ice core after 1980 CE (Fig. 3b, c). These results suggest that biomassburning plumes of pine, larch, spruce and fir trees in Siberian regions have a more substantial influence on Kamchatka, southeastern Russia (facing the western North Pacific Rim), than southern Alaska (facing the eastern North Pacific Rim).

We found that concentrations of dehydroabietic acid in the Alaskan ice core after the 1980s were higher than those of levoglucosan, which is consistent with Kamchatka records (Kawamura et al., 2012). This further suggests that biomassburning plumes from Siberian boreal conifer trees could be transported to the North Pacific regions including the eastern North Pacific Rim. It also suggests that eastern Asian regions (broadleaf trees are common) could be important for levoglucosan rather than dehydroabietic acid (boreal forest fires in Siberia, where pine trees are dominant). For instance, correlations of levoglucosan versus dehydroabietic and vanillic acid from 1660 to 1840 are weak but significant $(\tau=0.37$ and 0.33 , respectively; $p<0.05$ ), suggesting the presence of a common source region. Correlation of levoglucosan with dehydroabietic and vanillic acids from 1920 to 1977 are not significant (0.11 and 0.14 , respectively). On the other hand, vanillic vs. dehydroabietic acid showed a significant correlation $(0.41 ; p<0.01)$, suggesting a different source region for levoglucosan. Back-trajectory analysis $(500 \mathrm{hPa})$ of air masses (2002-2007 CE), together with fire counts, also showed that sources regions also include Mongolia, China and Japan (Fig. 2a-f). Yasunari and Yamazaki (2009) reported that Alaska can receive air masses from eastern Asia and Japan in the troposphere $(>300 \mathrm{hPa})$. The Kamchatka Peninsula can also receive air masses from these regions (Kawamura et al., 2012).

These results showed some similarity in the records of levoglucosan between Kamchatka and Alaskan ice cores (except for few points) and some discrepancies of dehydroabietic acid between two sampling sites. Dehydroabietic acid concentrations gradually increased in the Kamchatka ice core after the 1950s. The Alaskan ice core showed an increase after the 1970s (Fig. 4e), suggesting that conifer-burning plumes could be transported significantly to Kamchatka as well, but not to southern Alaska, in the 1950s to the 1980s. There is another possibility for this discrepancy between two sites; i.e., dehydroabietic acid could be decomposed during long-range atmospheric transport (Simoneit and Elias, 2001) from Siberia to southern Alaska, although it could easily reach Kamchatka in the western North Pacific Rim. The Kamchatka ice core also did not show high spikes (except 1970) in the 1950s to the 1970s. Such types of lower spikes and/or sporadic peaks of levoglucosan and dehydroabietic acid after the 1910s (Fig. 3a, b) and the correlations suggest that source regions are different (e.g., eastern Asian broadleaf trees and Siberian boreal forest and pine trees) or that regional transport overwhelms the long-range atmospheric transport of dehydroabietic acid rather than levoglu- 
cosan over the saddle of Aurora Peak, at least after the 1910s. Interestingly, dehydroabietic acid showed an increasing trend from the 1980s onwards, with higher concentrations than levoglucosan, being consistent with the Kamchatka ice core (Kawamura et al., 2012).

Annual composite maps (Fig. 2a-f) of MODIS from 2001 to 2007 show a continental outflow of air masses from Eurasia to the Aurora site, generally supporting the above results and implications for the Alaskan ice core. However, we detected higher spikes of levoglucosan (in 2004, 2005 and $2006 \mathrm{CE}$, with 95, 598 and $131 \mathrm{ng}$ per $\mathrm{kg}$ ice, respectively), dehydroabietic acid (in 2004, 2006 and 2007 CE with 309, 298 and $556 \mathrm{ng}$ per $\mathrm{kg}$ ice, respectively) and vanillic acid (in 2005, 2006 and 2007 CE with 18.6, 7.30 and 12.7 ng per kg ice) within these years, suggesting that they have different sources. It is well known that 2004 is the year of biomass burning in Alaska. The concentration of dehydroabietic acid in 2004 ( $309 \mathrm{ng}$ per $\mathrm{kg}$ ice) is 3 times higher than levoglucosan (95.3 ng per kg ice; see Fig. 3), suggesting that boreal forest fires associated with conifer trees followed by shortand long-range atmospheric transport are more important in recent decades in the Northern Hemisphere.

\subsection{Vanillic acid}

We detected VA in the ice core from Aurora Peak (Fig. 3c), which is a biomass-burning tracer of lignin (Simoneit et al., 1993). Particularly, vanillic acid can be produced by incomplete combustion of conifer trees, i.e., conifer-rich boreal forest (Simoneit et al., 1993; Pokhrel, 2015). We found that the levels of vanillic acid are very low between the 1830s and 1960s, as shown in Fig. 3c. Higher spikes of a lignin tracer were detected in the following years: $1678(3.25 \mathrm{ng}$ per $\mathrm{kg}$ ice), 1692 (3.23 ng per $\mathrm{kg}$ ice), 1695 (5.56 ng per $\mathrm{kg}$ ice), 1732 (3.98 ng per $\mathrm{kg}$ ice), 1786 (3.60 ng per $\mathrm{kg}$ ice), 1814 (11.0 ng per kg ice), 1818 (5.50 ng per kg ice), 1973 (5.52 ng per $\mathrm{kg}$ ice), 1989 (3.57 ng per $\mathrm{kg}$ ice), 1993 (2.66 ng per $\mathrm{kg}$ ice), 1996 (4.66 ng per $\mathrm{kg}$ ice), 1997 (3.57 ng per $\mathrm{kg}$ ice), 1999 (3.57 ng per kg ice), 2001 (3.26 ng per kg ice) and 2007 (18.6 ng per $\mathrm{kg}$ ice). We found that the spikes of vanillic acid are not consistent with those of levoglucosan in the ice core during the periods (Fig. 3). In particular, in more recent years, after 1990, vanillic acid showed a clear abrupt increase in the ice core, which is consistent with the increase in dehydroabietic acid but different from levoglucosan (Fig. 3). The abrupt increase in vanillic acid in the Alaskan ice core is consistent with that of the Kamchatka ice core (Kawamura et al., 2012).

The higher concentrations and similarity of vanillic and dehydroabietic acids in the Alaskan ice core after 1990 suggests the enhanced emission of biomass-burning products of conifer trees and lignin in the boreal forests in Alaska, which could be imprinted in the southern Alaskan ice core. Interestingly, we found a significant correlation (Fig. 5a) between dehydroabietic acid (except for $2005 \mathrm{CE}$ ) and vanillic acid
( $\tau=0.60, p<0.01$ ) after the 1990s, a period corresponding to the GPCS (1977-2007 CE). Being consistent with the warmer sea surface temperature in the eastern North Pacific Rim during the GPCS periods (Meehl et al., 2009), southern Alaska is influenced by the warmer temperature and dryness, which triggered a higher chance of forest fire occurrence in the boreal forests, causing more emissions of conifer and lignin tracers over the southern Alaskan atmosphere (Figs. 3 and 4). Interestingly, the Kamchatka ice core also showed an increased concentration of these tracers after the 1970s (Kawamura et al., 2012).

Vanillic acid in the Alaskan ice core showed a different trend from the Svalbard ice core (Fig. 4e) after the GPCS (1976-1977), suggesting different source regions. Dehydroabietic acid exhibits a similar trend to $p$-hydroxybenzoic acid ( $p$-HBA) of the Svalbard ice core (Grieman et al., 2018a). $p$-HBA is produced from tundra grasses and peat species, suggesting that a similar source is northern Asia, including Siberia. Its ice core record may be driven by climate in the North Pacific Rim. In contrast, the historical trend of vanillic acid from the 1770 s to the 1950 s is similar to that (depressed trend) of the Tunu, Greenland, ice core, except for few years, namely 1851, 1870, 1880, 1934 and 1946 (Fig. 4c), which implies that long-range atmospheric transport from Russia may be a likely source. These two trends diverge markedly from the 1950s onwards. In addition, vanillic acid in this study exhibits a similar trend to $p$-HBA and vanillic acid in the ice core from Akademii Nauk (Grieman et al., 2017) from the 1890 s to the 1980 s (Fig. 4d).

These results suggest that Alaskan glaciers showed nonstationary multidecadal variability in biomass-burning tracers from tundra grasses and peat species. Notably, during the 1660 s to 1820 s, vanillic acid, dehydroabietic acid and levoglucosan have higher spikes (Fig. $4 a, b, c)$ at four to nine points, which is common in other ice cores (Fig. 4a-d) in the NH. After these higher spikes, a global (at least Tunu, Akademii Nauk and Aurora) depression of vanillic acid and $p$-HBA (1830s-1950) can be observed (e.g., Fig. 4a-d) in the $\mathrm{NH}$, suggesting that similarity and variability in these acids are temporally and spatially heterogeneous in the $\mathrm{NH}$ under the climate-driven forces. Historical trends of biomassburning tracers from this and other ice core studies, together with back trajectories (Fig. 2a-f), suggest a common potential source region of northern Asia and North America, which are characterized by fire activities of boreal tundra woodlands, boreal conifer forests and peat.

Dehydroabietic acids and $p$-HBA may be more unstable compared to photodegradation of levoglucosan during longrange transport. For instance, a higher sensitivity of dehydroabietic acid was reported compared to levoglucosan ( $\mathrm{Si}$ moneit and Elias, 2001; Simoneit, 2002). It should be noted that we did not detect $p$-HBA, which can be produced from incomplete combustion of grasses (Simoneit, 2002; Kawamura et al., 2012), although $p$-HBA was detected in the Kamchatka ice core (Kawamura et al., 2012). In contrast, 


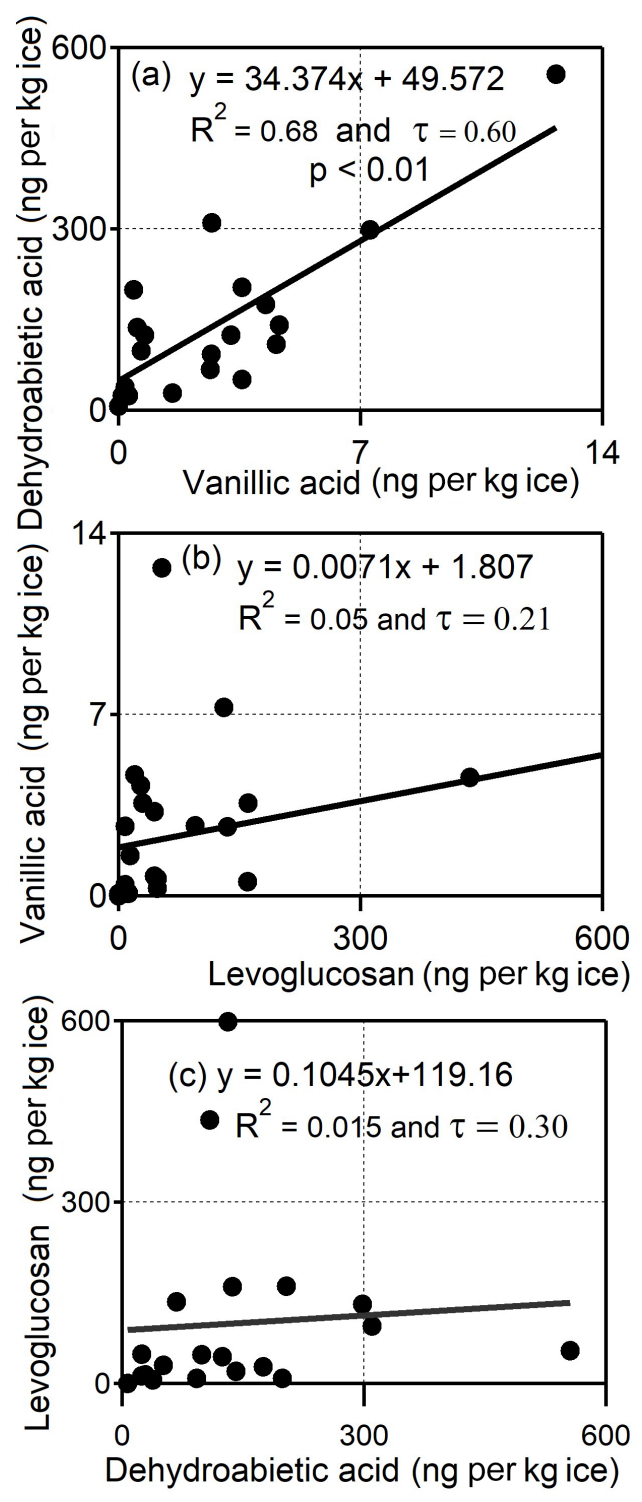

Figure 5. Correlation (Pearson: $R^{2}$; Kendall: $\tau$ ) plots between the concentrations of (a) dehydroabietic and vanillic acids, (b) vanillic acid and levoglucosan, and (c) levoglucosan and dehydroabietic acid. In (b, c), correlations are insignificant in the Alaskan ice core records from the saddle of Aurora Peak after the Great Pacific Climate Shift (1977-2007 CE).

we detected significant amounts of dehydroabietic acid from 1665 to 2007 in this study (Fig. 3b). Hence, we may speculate that $p$-HBA could be more unstable compared to levoglucosan, dehydroabietic acid and vanillic acid during longrange atmospheric transport.

Moreover, the historical trend of vanillic acid from 1800 to 2000 in the Greenland ice core (McConnell et al., 2007) is entirely different from that of this study. Besides, the historical trend of vanillic acid shows many higher sporadic peaks during the LIA and extended LIA (ELIA); this is somewhat similar to concentration trends of 10-year bin averages of $p$ HBA and vanillic acid from the Svalbard ice core (Grieman et al., 2018a). These similarities could be due to a similar source and similar source regions. In contrast, dissimilarity of historical records of these compounds before and after ELIA suggests that the shifting of the atmospheric circulation or different spatial patterns of biomass burning and/or that climate-driven effects are deeply involved (Pokhrel et al., 2015). Hence these results further support a change of biomass-burning periodic cycles of alpine glaciers in the North Pacific Rim.

\subsection{Biomass-burning tracers, temperature and climate: atmospheric consequences}

There is a direct relationship between the atmospheric temperature and pressure in the $\mathrm{NH}$; that is, one variable (temperature or pressure) follows the same change when it comes to the increasing and decreasing mode. This mechanism drives the atmospheric air mass from one place to another in the NH. For example, the semi-permanent Siberian High and Azores High drive the air mass from those regions to Alaska (e.g., Aleutian Low) and Iceland (e.g., winter air mass circulation) in the NH (Mantua and Hare, 2002). This Siberian high-pressure system (the vertical extent is up to $3 \mathrm{~km}$ from the surface) is one of the principal sources of polar air mass in the $\mathrm{NH}$ and is a principal factor for controlling air pollution in Alaska; $10 \mathrm{~d}$ air mass back trajectories (Fig. 2a-f) supported the same atmospheric transport pathways to southern Alaska. The consequences of such an atmospheric circulation in Alaskan can be directly observed with the correlations of monthly (annual and seasonal) records of global lower-tropospheric temperature anomalies (GLTTAs) with this study (Fig. 6a-o).

These pieces of evidence are further reflected by the Pacific Decadal Oscillation (PDO), which is characterized by relatively high temperatures from the western to eastern coasts of the North Pacific Rim (Mantua et al., 1997; MacDonald and Case, 2005; Shen et al., 2006). A similar trend of levoglucosan with a five-point running average of this PDO cycle, except for a few points (e.g., 1750, 1834, 1870, 1913, 1934 and 1966) during the whole period of 1665 to 1995 , represents ecological changes and/or changes in climate-driven biomass-burning activities. These years, that is, 1750, 1834, $1870,1913,1934$ and $1966 \mathrm{CE}$, are influenced by microscale and mesoscale rather than synoptic- and global-scale weather conditions and/or by long spikes represented by single fire events or seasonal biomass-burning activities (Fig. 7a, b). Hence, the positive and negative phase of PDO represents zonal and/or meridional flows and elevated and depressed transport of levoglucosan to the eastern North Pacific Rim.

In addition, winter precipitation (i.e., snowfall) is higher than usual in the Alaskan coast. The annual precipitation of Aurora is increasing. The positive correlations $\left(R^{2}\right.$ or $\left.\tau\right)$ of levoglucosan (except for few points: 1993, 1997, 1999 and 


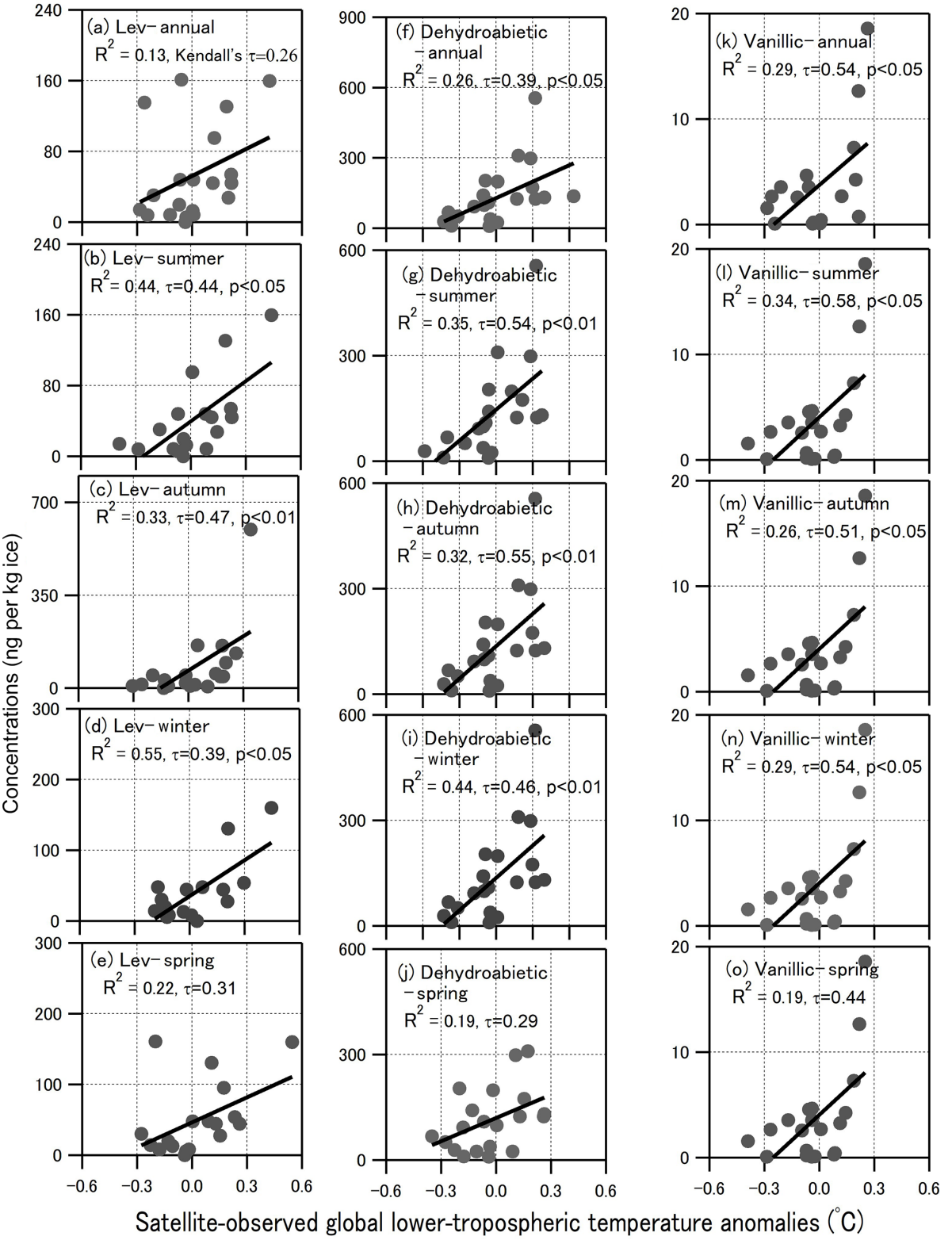

Figure 6. Correlation (Pearson: $R^{2}$; Kendall: $\tau$ ) plots between satellite-observed global lower-tropospheric temperature anomalies (i.e., microwave-sounding-unit temperature anomalies $\left({ }^{\circ} \mathrm{C}\right)$ of annual and seasonal records) and annual concentrations of (a-e) levoglucosan, (f-j) dehydroabietic acid and (k-o) vanillic acid after the Great Pacific Climate Shift in the Northern Hemisphere (1981-2008 CE).

2005), dehydroabietic (except for 1991 and 1998) and vanillic acids (except for 1998 and 2002) with winter temperature (GLTTA) are $0.55,0.44$ and 0.29 , respectively, after the Great Pacific Climate Shift (see Fig. 6). When the pressure decreases, the temperature decreases, transporting air mass from higher-pressure (e.g., eastern Asia) to lower-pressure regions (Alaska). Similarly, we found further evidence of long-range atmospheric transport due to a strong pressure gradient between Alaskan (e.g., Aleutian Low) and eastern Asian regions (e.g., Siberian High). For example, the correlations $\left(R^{2}\right.$ and $\left.\tau\right)$ of these three compounds (except for a few points) are all positive with seasonal (i.e., summer, autumn, and spring) and annual records of temperatures (see Fig. 6ao). In addition, the terrestrial-plant-derived biomarkers such as homologous series of high-molecular-weight fatty acids $\left(C_{21: 0}\right.$ to $\left.C_{30: 0}\right)$ showed increasing trends after the GPCS from the same ice core. These acids are emitted to the source regions by the vaporization of leaf wax during biomassburning processes (Pokhrel et al., 2015; Pokhrel, 2015). Hence, these tracers are associated with synoptic-scale radiative climate forcing (e.g., radiative lapse rate or temperature inversion) from the surface to the boundary layer. The 

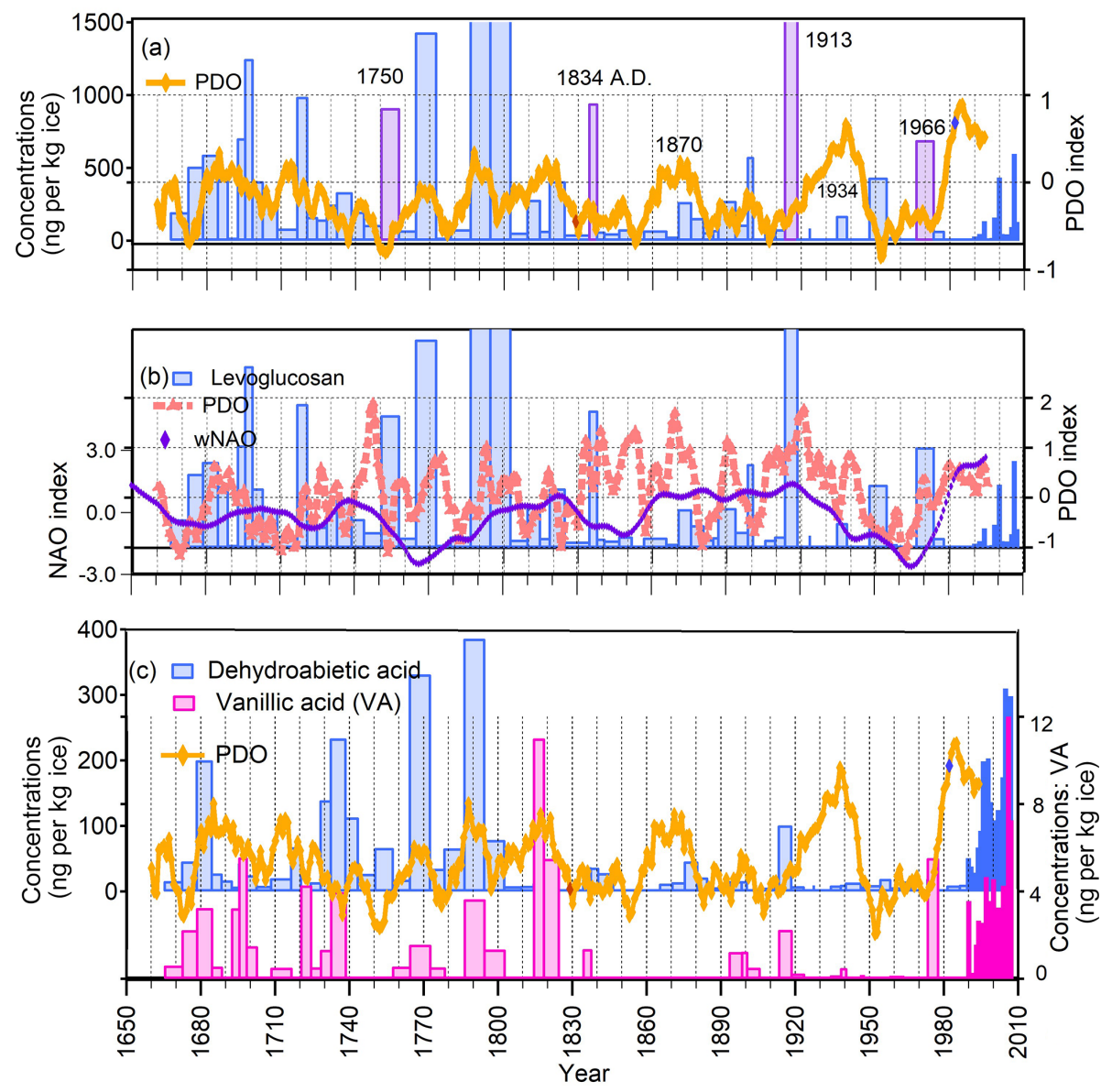

Figure 7. Historical trends in the concentrations of (a) levoglucosan (Aurora Peak) and Pacific Decadal Oscillation (PDO 5-year mean) index (Shen et al., 2006); (b) levoglucosan (Aurora Peak), PDO 5-year mean index (MacDonald and Case, 2005) and Multi-decadal Winter North Atlantic index (wNAO; Trouet et al., 2009); and (c) dehydroabietic and vanillic acids and PDO index (Shen et al., 2006) for 1665-2008 CE.

downslope winds and drainage of wind in Alaska may be associated with the PDO and ENSO in the summer (MacDonald and Case, 2005; Shen et al., 2006).

The remarkable increasing trend of dehydroabietic acid (average: $128 \mathrm{ng}$ per kg ice; range: $6.59-555, \mathrm{SD} \pm 126$; median: 108.8) occurred after the GPCS (1977-2007 CE). We found a significant correlation (Fig. 5a) between dehydroabietic acid (except for 2005) and vanillic acid $(\tau=0.60$; $p<0.01)$. In contrast, we found insignificant correlations of levoglucosan with dehydroabietic acid (0.30; except for 1981 and 1986) and vanillic acid (0.21; except for 1999 and 2005) after the GPCS, that is, 1977-2007 CE, revealing the local source of emissions. For example, the biomass-burning year of Alaska is 2004, which shows 3 times higher concentrations of dehydroabietic acid (309 ng per kg ice) than levoglucosan (95.3 ng per kg ice), suggesting that short-range atmospheric transport enhances the dehydroabietic acid under the local weather condition of Alaska.

The historical record of $\delta \mathrm{D}$ of the same ice core is well correlated with the PDO cycle (Tsushima et al., 2015). Levoglu- cosan levels of this study also correspond to the periodicity of PDO (Fig. 7a, b) due to the Aleutian Low of the North Pacific Ocean, which is atmospheric air mass convergent near the southeastern coast of Alaska (e.g., Aleutian Low represents the positive PDO). The average annual amplitude of $\delta \mathrm{D}$ from this ice core is $30.9 \%$ (Tsushima et al., 2015). This high amplitude of $\delta \mathrm{D}$ could not be conserved if $100 \%$ of snowmelt occurred in the past. The coastal record of climate change (e.g., winter storm development) of the Gulf of Alaska is well correlated to the GPCS (1976 CE) in the PDO, suggesting that $\delta \mathrm{D}$ indicates the air temperature of the saddle of the Aurora Peak.

The higher spikes of levoglucosan are similar to those of dehydroabietic and vanillic acids from the 1660s to the 1970s. The positive and negative phases of both PDO occurrences (MacDonald and Case, 2005; Trouet et al., 2009) cover all higher and lower spikes of levoglucosan. The corresponding phase (positive and negative) of the PDO varies from a year to several years and exhibits a tendency to cover historical intervals of these compounds lasting several 
decades, from the 1660 s to the 1970s. The NAO or winter NAO (wNAO) phase remains the same for several years when compared to the PDO from same ice core (Pokhrel et al., 2015), as shown in Fig. 7b. The periodicity of the NAO phase (positive and negative) does not represent the historical trends (higher spikes and depression) of levoglucosan, dehydroabietic and vanillic acids (Fig. 7b, c). This NAO represents atmospheric circulation between the subtropical high and polar low (Trouet et al., 2009). In fact, the NAO significantly dominates the North Atlantic (e.g., North America) and European winter climate variabilities rather than those of northern Asia (i.e., Eurasia and Siberia), which is spontaneously inappropriate in this study.

\section{Summary and conclusions}

This study has been conducted to better understand how temporal trends of the forest fire signal in the ice core depend on the source region and proximity to the source and types of vegetation in the source regions of southern Alaska since the 1660s. Ice core records of dehydroabietic acid, vanillic acid and levoglucosan showed predominant multidecadal trends, suggesting the variations in fire regimes and the proximity to the source and changes in atmospheric circulation, land use and/or ecological patterns in the midlatitudes to high latitudes $\left(\geq 30^{\circ} \mathrm{N}\right)$ at least before and after the 1830s and after the Great Pacific Climate Shift (GPCS). Levoglucosan showed sporadic peaks from the 1660 s to the 1830 s and single spikes in 1898, 1913, 1966 and 2005 CE. These spikes indicate a significant contribution of biomass and/or biofuel burning attributed to their source-specific emission and atmospheric stability in Alaska.

Dehydroabietic and vanillic acids showed similar historical trends with levoglucosan before the 1830s, suggesting that hardwood and conifer trees (e.g., resin and lignin boreal conifer trees, deciduous trees, and other higher plants) and perennial grasses $\left(C_{3}\right.$ and $C_{4}$ plants) were simultaneously important as burning sources. The gradually increasing concentration trends of dehydroabietic and vanillic acids from the 1980s onward show a strong correlation $(\tau=0.60, p<$ 0.01; after the GPCS; 1976), suggesting significant changes in either burning patterns (i.e., new land-use pattern or new ecological pattern) or atmospheric circulation over Alaska by the climate-driven forces exhibiting similar signals of biomass-burning tracers as opposed to insignificant correlation of levoglucosan with these compounds.

The significant positive correlations $(\tau)$ of these three compounds with global lower-tropospheric (annual and seasonal) temperature anomalies (GLTTAs) suggest that Alaskan snow precipitation was involved with climate-driven forces from the end of the GPCS onwards. These tracers are correlated with synoptic- and global-scale radiative climate forcing (e.g., radiative atmospheric lapse rate or inversion) from the surface to the atmospheric boundary layer. The se- ries of higher (lower) spikes of biomass-burning tracers from Aurora Peak represent the positive (negative) phase of PDO periodicity cycles in the North Pacific Rim. The correlations of temperature and comparison with the PDO cycle in this study further prove the excellent signal of the periodic cycle of a climate-driven regime, namely atmospheric activities, climate and weather conditions, ecological changes, and individual fire activities of source regions to the Aurora site.

The straightforward historical trends of these three compounds were significant before the 1830s; this differs from the Kamchatka ice core record, suggesting that there are some differences between the western and eastern North Pacific Rim in terms of the emission, frequency and deposition. The concentrations of these three compounds from Aurora Peak are higher than those from other ice core studies in the NH (e.g., Kamchatka, Svalbard, Tunu and Akademii Nauk). In contrast, there are similarities in the depressed concentration trend of Aurora with other ice core studies at least for 100 years (e.g., from the 1890s to the 1980s: Akademii Nauk; 1820-1960: Tunu, Greenland), suggesting that sources of biomass-burning tracers are further confined within the same regions, traveling from very long distances, and are well captured within the snow particles. If it is true, these compounds might be involved as cloud condensation nuclei from the surface to $15.2 \mathrm{~km}$ (i.e., cumulonimbus cloud) are transported thousands kilometers to Aurora. This gives positive feedback for the climate change and/or climate variability in the North Pacific Rim.

Data availability. Data are available upon request to the corresponding author.

Author contributions. KK designed the research plan. AP and BK analyzed ice samples and wrote the paper. KO and AT also helped to prepare the data set of the ice core. SM and TS provided ice core samples and were responsible for field logistics. OS provided suggestions during the writing process.

Competing interests. The authors declare that they have no conflict of interest.

Acknowledgements. This study was partly supported by the Japan Society for the Promotion of Science (JSPS) through grant in aid (nos. 19340137 and 24221001) and the Japan Student Services Organization (JASSO). We also acknowledge the support from the Institute of Low Temperature Science, Hokkaido University, for the ice core program.

Financial support. This research has been supported by the Japan Society for the Promotion of Science (JSPS) (grant nos. 19340137 and 24221001.). 
Review statement. This paper was edited by Carlo Barbante and reviewed by three anonymous referees.

\section{References}

Achard, F., Eva, H. D., Mollicone, D., and Beuchleet, R.: The effect of climate anomalies and human ignition factor on wildfires in Russian boreal forests, Phil. Trans., R. Soc., B., 363, 2329e2337, https://doi.org/10.1098/rstb.2007.2203, 2008.

Andreae, M. O. and Merlet, P.: Emission of trace gases and aerosols from biomass burning, Global Biogeochem. Cy., 15, 955-966, 2001.

Balzter, H., Gerard, F., Weedon, G., Grey, W., Combal, B., Bartholome, E., Bartalev, S., and Los, S.: Coupling of vegetation growing season anomalies with hemispheric and regional scale climate patterns in Central and East Siberia, J. Climate, 20, 3713e3729, https://doi.org/10.1175/JCLI4226, 2007.

Davidson, C. I., Jaffrezo, J.-L., Small, M. J., Summers, P. W., Olson, M. P., and Borys, R. D.: Trajectory analysis of source regions influencing the south Greenland ice sheet during the DYE3 gas and aerosol sampling program, Atmos. Environ., 27A, 2739-2749, 1993.

Divine, D., Isaksson, E., Martma, T., Meijer, H. A. J., Moore, J., Pohjola, V., van de Wal, R. S. W., and Godtliebsen, F.: Thousand years of winter surface air temperature variations in Svalbard and northern Norway reconstructed from ice-core data, Polar Res., 30, 7379, https://doi.org/10.3402/polar.v30i0.7379, 2011.

Eichler, A., Brütsch, S., Olivier, S., Papina, T., and Schwikowski, M.: A 750 year ice core record of past biogenic emissions from Siberian boreal forests, Geophys. Res. Lett., 36, L18813, https://doi.org/10.1029/2009GL038807, 2009.

Eichler, A., Willy, T., Brütsch, S., Olivier, S., Papina, T., and Schwikowski, M.: An ice-core based history of Siberian forest fires since AD 1250, Quaternary Sci. Rev. 30, 1027e1034, https://doi.org/10.1016/j.quascirev.2011.02.007, 2011.

Engling, G., Carrico, C. M., Kreidenweis, S. M., Collett, J. L., Day, D. E., Malm, W. C., Lincoln, E., Hao, W. M., Iinuma, Y., and Herrmann, H.: Determination of levoglucosan in biomass combustion aerosol by high-performance anion-exchange chromatography with pulsed amperometric detection, Atmos. Environ., 40, 299-311, 2006.

Fraser, M. P. and Lakshmanan, K.: Using levoglucosan as a molecular marker for the long-range transport of biomass combustion aerosols, Environ. Sci. Technol., 34, 4560-4564, 2000.

Fu, P. Q., Kawamura, K., Okuzawa, K., Agarwal, S. G., Wang, G., Kanaya, Y., and Wang, Z.: Organic molecular compositions and temporal variations of summertime mountain aerosols over Mt. Tai, North China Plain, J. Geophys. Res.-Atmos., 113, D19107, https://doi.org/10.1029/2008JD009900, 2008.

Fu, P. Q., Kawamura, K., Pavuluri, C. M., Swaminathan, T., and Chen, J.: Molecular characterization of urban organic aerosol in tropical India: contributions of primary emissions and secondary photooxidation, Atmos. Chem. Phys., 10, 2663-2689, https://doi.org/10.5194/acp-10-2663-2010, 2010.

Fu, P., Kawamura, K., and Miura, K.: Molecular Characteristics of Marine Organic Aerosols Collected during a Roundthe-World Cruise, J. Geophys. Res.-Atmos., 116, D13302, https://doi.org/10.1029/2011JD015604, 2011.
Gambaro, A., Zangrando, R., Gabrielli, P., Barbante, C., and Cescon, P.: Direct Determination of Levoglucosan at the Picogram per Milliliter Level in Antarctic Ice by HighPerformance Liquid Chromatography/Electrospray Ionization Triple Quadrupole Mass Spectrometry, Anal. Chem., 805, 16491655, 2008.

Gao, S., Liu, D., Kang, S., Kawamura, K., Wu, G., Zhang, G., and Cong, Z.: A new isolation method for biomass-burning tracers in snow: measurements of p-hydroxybenzoic, vanillic, and dehydroabietic acids, Atmos. Environ., 122, 142-147, 2015.

Grieman, M. M., Greaves, J., and Saltzman, E. S.: A method for analysis of vanillic acid in polar ice cores, Clim. Past, 11, 227232, https://doi.org/10.5194/cp-11-227-2015, 2015.

Grieman, M. M., Aydin, M., Fritzsche, D., McConnell, J. R., Opel, T., Sigl, M., and Saltzman, E. S.: Aromatic acids in a Eurasian Arctic ice core: a 2600-year proxy record of biomass burning, Clim. Past, 13, 395-410, https://doi.org/10.5194/cp-13-3952017, 2017.

Grieman, M. M., Aydin, M., Isaksson, E., Schwikowski, M., and Saltzman, E. S.: Aromatic acids in an Arctic ice core from Svalbard: a proxy record of biomass burning, Clim. Past, 14, 637651, https://doi.org/10.5194/cp-14-637-2018, 2018a.

Grieman, M. M., Aydin, M., McConnell, J. R., and Saltzman, E. S.: Burning-derived vanillic acid in an Arctic ice core from Tunu, northeastern Greenland, Clim. Past, 14, 1625-1637, https://doi.org/10.5194/cp-14-1625-2018, 2018b.

Hennigan, C. J., Sullivan, A. P., Collett Jr., J. L., and Robinson, A. L.: Levoglucosan stability in biomass burning particles exposed to hydroxyl radicals, Geophys. Res. Lett., 37, L09806, https://doi.org/10.1029/2010GL043088, 2010.

Hoffmann, D., Tilgner A., Iinuma, Y., and Herrmann, H.: Atmospheric stability of levoglucosan: a detailed laboratory and modeling study. Environ. Sci. Technol., 44, 694-699, https://doi.org/10.1021/es902476f, 2010.

Holdsworth, G., Krouse, H. R., and Nosal, M.: Ice core climate signals from Mount Logan, Yukon AD. 1700-1987, in: Climate since AD 1500, edited by: Bradley, R.S. and Jones, P. D., Routledge, New Yourk, NY, 483-504, 1992.

Holdsworth, G., Higuchi, K., Zielinski, G. A., Mayewski, P. A., Wahlen, M., Deck, B., Chylek, P., Johnson, B., and Damiano, P.: Historical biomass burning: Late 19th century pioneer agriculture revolution in northern hemisphere ice core data and its atmospheric interpretation, J. Geophys. Res., 101, 317-323, 1996.

Isaev, A. S., Korovin, G. N., Bartalev, S. A., Ershow, D. V., and Janetos, A.: Using remote sensing to assess Russian forest fire carbon emissions, Clim. Change, 55, 235e249, https://doi.org/10.1023/A:1020221123884, 2002.

Ivanova, G. A., Ivanov, V. A., Kukavskaya, E. A., and Soja, A. J.: The frequency of forest fires in Scots pine stands of Tuva, Russia, Environ. Res. Lett., 5, 015002, https://doi.org/10.1088/17489326/5/1/015002, 2010.

Jordan, T. B., Seen, A. J., and Jacobsen, G. E.: Levoglucosan as an atmospheric tracer for wood smoke, Atmos. Environ., 40, 53165321, 2006.

Kaplan, Y., Wake, C. P., Kreutz, K. J., and Whitlow, S. I.: A 1000yr record of forest fire activity from Eclipse Icefield, Yukon, Canada, The Holocene, 16, 200-209, 2006.

Kaufmann, P., Fundel, F., Fischer, H., Bigler, M., Ruth, U., Udisti, R., Hansson, M., De Angelis, M., Barbante, C., Wolff, E. W., 
Hutterli, M., and Wagenbach, D.: Ammonium and non-sea salt sulfate in the EPICA ice cores as indicator of biological activity in the Southern Ocean, Quaternary Sci. Rev., 29, 313-323, https://doi.org/10.1016/j.quascirev.2009.11.009, 2010.

Kawamura, K., Yokoyama, K., Fujii, Y., and Watanabe, O.: A Greenland ice core record of low molecular weight dicarboxylic acids, ketocarboxylic acids and $\alpha$-dicarbonyls: A trend from Little Ice Age to the present (1540 to 1989 A.D.), J. Geophys. Res., 106, 1331-1345, 2001.

Kawamura, K., Izawa, Y., Mochida, M., and Shiraiwa, T.: Ice core records of biomass burning tracers (levoglucosan and dehydroabietic, vanillic and p-hydroxybenzonic acids) and total organic carbon for past 300 years in the Kamchatka Peninsula, Northeast Asia, Geochim. Cosmochim. Acta., 99, 317-329, https://doi.org/10.1016/j.gca.2012.08.006, 2012.

Kehrwald, N., Zangrando, R., Gabrielli, P., Jaffrezo, J. L., Boutron, C., Barbante, C., and Gambaro, A.: Levoglucosan as a specific marker of fire events in Greenland snow, Tellus B, 64, 18196, https://doi.org/10.3402/tellusb.v64i0.18196, 2012.

Keywood, M., Kanakidou, M., Stohl, A., Dentener, F., Grassi, G., Meyer, C. P., Torseth, K., Edwards, D., Thompson, A. M., Lohmann, U., and Burrows, J.: Fire in the Air: Biomass burning impacts in a changing climate, Crit. Rev. Environ. Sci. Technol, https://doi.org/10.1080/10643389.10642011.10604248, 2011.

Kuo, L. J., Louchouarn, P., and Herbert, B. E.: Influence of combustion conditions on yields of solvent-extractable anhydrosugars and lignin phenols in chars: Implications for characterizations of biomass combustion residues, Chemosphere, 85, 797-805, 2011.

Lai, C., Liu, Y., Ma, J., Ma, Q., and He, H.: Degradation kinetics of levoglucosan initiated by hydroxyl radical under different environmental conditions, Atmos. Environ., 91, 32-39, https://doi.org/10.1016/j.atmosenv.2014.03.054, 2014.

Lamarque, J.-F., Bond, T. C., Eyring, V., Granier, C., Heil, A., Klimont, Z., Lee, D., Liousse, C., Mieville, A., Owen, B., Schultz, M. G., Shindell, D., Smith, S. J., Stehfest, E., Van Aardenne, J., Cooper, O. R., Kainuma, M., Mahowald, N., McConnell, J. R., Naik, V., Riahi, K., and van Vuuren, D. P.: Historical (1850-2000) gridded anthropogenic and biomass burning emissions of reactive gases and aerosols: methodology and application, Atmos. Chem. Phys., 10, 7017-7039, https://doi.org/10.5194/acp-10-7017-2010, 2010.

Legrand, M. and De Angelis, M.: Light carboxylic acids in Greenland ice: A record of past forest fires and vegetation emissions from the boreal zone, J. Geophys. Res., 101, 4129-4145, 1996.

Legrand, M. and Mayewski, P. A.: Glaciochemistry of polar ice cores: A review, Rev. Geophys., 35, 219-143, 1997.

Legrand, M., De Angelis, M., Staffelbach, T., Neftel, A., and Stauffer, B.: Large perturbations of ammonium and organic acids content in the Summit Greenland ice core, fingerprint from forest fires?, Geophys. Res. Lett., 19, 473-475, 1992.

Legrand, M., McConnell, J., Fischer, H., Wolff, E. W., Preunkert, S., Arienzo, M., Chellman, N., Leuenberger, D., Maselli, O., Place, P., Sigl, M., Schüpbach, S., and Flannigan, M.: Boreal fire records in Northern Hemisphere ice cores: a review, Clim. Past, 12, 2033-2059, https://doi.org/10.5194/cp-12-2033-2016, 2016.

MacDonald, G. M. and Case, R. A.: Variations in the Pacific Decadal Oscillation over the past millennium, Geophys. Res. Lett., 32, L08703, https://doi.org/10.1029/2005GL022478, 2005.
Mann, M. E., Zhang, Z., Rutherford, S., Bradley,R., Hughes, M. K., Shindell, D., Ammann, C., Faluvegi, G., and Ni, F.: Global signatures and dynamical origins of the Little Ice Age and Medieval Climate Anomaly, Science, 326, 1256-1260, https://doi.org/10.1126/science.1177303, 2009.

Mantua, N. J. and Hare, S. R.: The Pacific Decadal Oscillation, J. Oceanogr., 58, 35-44, 2002.

Mantua, N. J., Hare, S. R., Zhang, Y., Wallace, J. M., and Francis, R. C.: A Pacific interdecadal climate oscillation with impacts on salmon production, Am. Meteorol. Soc., 78, 1069-1079, 1997.

Marlon, J. R., Bartlein, P. J., Carcaillet, C., Gavin, D. G., Harrison, S. P., Higuera, P. E., Joos, F., Power, M. J., and Prentice, I. C.: Climate and human influences on global biomass burning over the past two millennia, Nat. Geosci., 1, 697-702, https://doi.org/10.1038/ngeo313, 2008.

McConnell, J. R., Edwards, P. R., Kok, G. L., Flanner, M. G., Zender, C. S., Saltzman, E. S., Banta, J. R., Pasteris, D. R., Carter, M. M., and Kahl, J. D. W.: 20th Century industrial black carbon emissions altered Arctic climate forcing, Science, 317, 13811384, https://doi.org/10.1126/science.1144856, 2007.

Meehl, G. A., Hu, A., Arblaster, J. M., Fasullo, J., and Trenberth, K. E.: Externally Forced and Internally Generated Decadal Climate Variability Associated with the Interdecadal Pacific Oscillation, J. Climate, 26, 7298-7310, https://doi.org/10.1175/JCLI-D-12$00548.1,2013$

Meehl, A. G., Hu, A., and Santer, D. B.: The mid-1970s cClimate shift in the Pacific and the relative roles of forced versus inherent decadal variability, J. Climate, 22, 780-792, https://doi.org/10.1175/2008JCLI2552.1, 2008.

Müller-Tautges, C., Eichler, A., Schwikowski, M., Pezzatti, G. B., Conedera, M., and Hoffmann, T.: Historic records of organic compounds from a high Alpine glacier: influences of biomass burning, anthropogenic emissions, and dust transport, Atmos. Chem. Phys., 16, 1029-1043, https://doi.org/10.5194/acp-161029-2016, 2016.

Olivier, S., Blaser, C., Brütsch, S., Frolova, N., Gäggeler, H. W., Henderson, K. A., Palmer, A. S., Papina, T., and Schwikowski, M.: Temporal variations of mineral dust, biogenic tracers, and anthropogenic species during the past two centuries from Belukha ice core, Siberian Altai., J. Geophys. Res., 111, D05309, https://doi.org/10.1029/2005JD005830, 2006.

Pokhrel, A.: Studies on ice core records of dicarboxylic acids, $\omega$ oxocarboxylic acids, pyruvic acid, $\alpha$-dicarbonyls and fatty acids from southern Alaska since $1665 \mathrm{AD}$ : A link to climate change in the Northern Hemisphere, Ph. D thesis, Hokkaido University, HUSCAP 11786, available at: http://hdl.handle.net/2115/59331 (last access: 19 November 2019), 2015.

Pokhrel, A., Kawamura, K., Ono, K., Seki, O., Matoba, S., and Shiraiwa, T.: Ice core profiles of saturated fatty acids $\left(C_{12: 0^{-}} C_{30: 0}\right)$ and oleic acid $\left(C_{18: 1}\right)$ from southern Alaska since 1734 AD: A link to climate change in the Northern Hemisphere, Atmos. Environ., 100, 201-209, 2015.

Pokhrel, A., Kawamura, K., Ono, K., Seki, O., Matoba, S., Shiraiwa, T., and Fu, P.: Ice core records of monoterpeneand isoprene-SOA tracers from Aurora Peak in Alaska since 1660s: Implication for climate change variability in the North Pacific Rim, Atmos. Environ., 130, 105-112, https://doi.org/10.1016/j.atmosenv.2015.09.063, 2016. 
Robock, A.: Surface cooling due to smoke from biomass burning, in: Global biomass burning, edited by: Levine, J. S., MIT press, Cambridge, Mass., 463-476, 1991.

Rubino, M., D’Onofrio, A., Seki, O., and Bendle, J. A.: Ice-core records of biomass burning,Anthropocene Rev., 3, 140-162, https://doi.org/10.1177/2053019615605117, 2016.

Savarino, J. and Legrand, M.: High northern latitude forest fires and vegetation emissions over the last millenium inferred from the chemistry of a central Greenland ice core, J. Geophys. Res., 103, 8267-8279, 1998.

Shafizadeh, F.: The chemistry of pyrolysis and combustion, Adv. Chem. Ser., 207, 491-529, 1984.

Shen, C., Wang, W. C., Gong, W., and Hao, Z.: A Pacific Decadal Oscillation record since $1470 \mathrm{AD}$ reconstructed from proxy data of summer rainfall over eastern China, Geophy. Res. Lett., 33, L03702, https://doi.org/10.1029/2005GL024804, 2006.

Shi, G., Wang, X. C., Li, Y., Trengove, R., Hu, Z., Mi, M., Li, X., $\mathrm{Yu}, \mathrm{J}$., Hunter, B., and He, T.: Organic tracers from biomass burning in snow from the coast to the ice sheet summit of East Antarctica, Atmos. Environ, 201, 231-241, 2019.

Simoneit, B. R. T.: Biomass burning-a review of organic tracers for smoke from incomplete combustion, Appl. Geochem., 17, 129162, 2004.

Simoneit, B. R. T. and Elias, V. O.: Detecting organic tracers from biomass burning in the atmosphere, Mar. Pollut. Bull., 42, 805$810,2001$.

Simoneit, B. R. T., Rogge, W. F., Mazurek, M. A., Standley, L. J., Hildemann, L. M., and Cass, G. R.: Lignin pyrolysis products, lignans, and resin acids as specific tracers of plant classes in emissions from biomass combustion, Environ. Sci. Technol., 27, 2533-2541, 1993.

Simoneit, B. R. T., Schauer, J. J., Nolte, C. G., Oros, D. R., Elias, V. O., Fraser, M. P., Rogge, W. F., and Cass, G. R.: Levoglucosan, a tracer for cellulose in biomass burning and atmospheric particles, Atmos. Environ., 33, 173-182, 1999.

Trouet, V., Esper, J., Graham, N. E., Baker, A., Scourse, J. D., and Frank, D. C.: Persistent Positive North Atlantic Oscillation mode dominated the medieval Climate anomaly, Science, 324, 78-80, https://doi.org/10.1126/science.1166349, 2009.

Tsai, Y. I., Sopajaree, K., Chotruksa, A., Wu, H. C., and Kuo, S. C.: Source indicators of biomass burning associated with inorganic salts and carboxylates in dry season ambient aerosol in Chiang Mai Basin, Thailand, Atmos. Environ., 78, 93-104, https://doi.org/10.1016/j.atmosenv.2012.09.040, 2013.
Tsushima, A.: A study on reconstruction of paleo-environmental changes in the northern North Pacific region from an alpine ice core, A Doctor's thesis, Hokkaido University, 78 pp., https://doi.org/10.14943/doctoral.k11790, 2015.

Tsushima, A., Matoba, S., Shiraiwa, T., Okamoto, S., Sasaki, H., Solie, D. J., and Yoshikawa, K.: Reconstruction of recent climate change in Alaska from the Aurora Peak ice core, central Alaska, Clim. Past, 11, 217-226, https://doi.org/10.5194/cp-11217-2015, 2015.

Verma, S. K., Kawamura, K., Chen, J., Fu, P., and Zhu, C.: Thirteen years of observations on biomass burning organic tracers over Chichijima Island in the western North Pacific: An outflow region of Asian aerosols, J. Geophys. Res.-Atmos., 120, 41554168, https://doi.org/10.1002/2014JD022224, 2015.

Wallenius, T. H., Pitkänen, A., Kuuluvainen, T., Pennanen, J., and Karttunen, H.: Fire history and forest age distribution of an unmanaged Picea abies dominated landscape, Can. J. For. Res., 35, 1540e1552, https://doi.org/10.1139/x05-050, 2005.

Whitlow, S., Mayewski, P., Dibb, J., Holdsworth, G., and Twickler, M.: An ice-core-based record of biomass burning in the Arctic and Subarctic, 1750-1980, Tellus, 46, 234-242, 1994.

Wolff, E. W.: Chemical signals of past climate and environment from polar ice cores and firn air, Chem. Soc. Rev., 41, 62476258, https://doi.org/10.1039/c2cs35227c, 2012.

Yang, Q., Mayewski, P. A., Whitlow, S., Twickler, M., Morrison, M., Talbot, R., Dibb, J. E., and Linder, E.: Global perspective of nitrate flux in ice cores, J. Geophys. Res., 100, 5113-5121, 1995.

Yasunari, T. J. and Yamazaki, K.: Origins of air mass over an Alaskan glacier and implications for ice core studies in the North Pacific regions, SOLA, 5, 77-80, https://doi.org/10.2151/sola.2009-020, 2009.

You $\mathrm{C}$ and $\mathrm{Xu} \mathrm{C} .:$ Review of levoglucosan in glacier snow and ice studies: Recent progress and future perspectives, Sci. Total Environ., 616-617, 1533-1539, doi:10.1016/j.scitotenv.2017.10.160, 2018.

Zennaro, P., Kehrwald, N., McConnell, J. R., Schüpbach, S., Maselli, O. J., Marlon, J., Vallelonga, P., Leuenberger, D., Zangrando, R., Spolaor, A., Borrotti, M., Barbaro, E., Gambaro, A., and Barbante, C.: Fire in ice: two millennia of boreal forest fire history from the Greenland NEEM ice core, Clim. Past, 10, 1905-1924, https://doi.org/10.5194/cp-10-1905-2014, 2014. 